\title{
Long Neglected Facts and the Vicious Circular Mechanism Behind the Middle-income Trap: An Explanation from the Debt Crisis Perspective
}

\author{
Xiangru Zhou ${ }^{1, *}$ \\ ${ }^{1}$ Northwest University, Xuefu Avenue, Chang'an District, Xi'an, Shaanxi 710127, China \\ *Corresponding author. Email: zhouxiangru@stumail.nwu.edu.cn
}

\begin{abstract}
The "middle-income trap" refers to the phenomenon that an economy stagnates for a long time after its income per capita achieves the middle level of the world, which frequently occurs in developing countries. Taking Latin America as an example, the author establishes a unified framework that includes other explanations from the perspective of the debt crisis for research. Adopting multiple methods including literature and case study, data analysis and mechanism reasoning, the main conclusions are as follows. First, middle-income economies bear a higher actual risk of external debt problems. Second, debt crises cause permanent losses and the recovery tends to be less effective in the middle-income group than others. Third, a lower yet concealed debt ratio threshold in the middle-income economies misleads the state government's decision-making on borrowing. Finally, "debtcrisis-recovery-debt", the vicious circle, systematically reveals the essence of the "middle-income trap" in the debtor countries, excessive sovereign debt serves as both the trigger and the accelerator in the collapsing process.
\end{abstract}

Keywords: Debt crisis, Middle-income trap, External debt, Vicious circle, Latin America.

\section{INTRODUCTION}

In 2006, the World Bank initially coined the "middle-income trap" the concept in East Asian Vision: Perspectives on Economic Development. Globally, there were 101 Middle-income economies in 1960 while only 13 of them successfully joined the rank of high-income countries by 2008. Nevertheless, the World Development Indicators (WDI) revealed that the GDP growth rate of these countries remained at $3.67 \%-6.24 \%$, while the average level of highincome groups from 2010 to 2017 was $0.77 \%$ $2.26 \%$. Hence, such a problem should not be intuitionally attributed to a constant low growth rate. Whether the middle-income trap does exist [1, $2,3,4]$, and if it does, what had caused most middle-income countries' falling into such a trap [1], [5], [6] have received considerable debate in the literature. In those on the Latin American debt crisis, studies have shown that the frequent debt crises since the 1980s are one of the reasons why Latin American countries fall into the middle- income trap [7], [8], but there is a general lack of more in-depth analysis and clear explanations.

Thus, this paper attempts to explain the puzzle of the middle-income trap from the perspective of the debt crisis and build a systematically unified framework to cover this and other existing explanations. This paper has the following innovations: First of all, middle-income traps are heterogeneously treated, which focuses on the rarely discussed perspective of the debt crisis, while divergent explanations can be integratedly included in a unified framework. Secondly, three longneglected facts of the middle-income economies are revealed and provide strong realistic evidence to the debt crisis perspective. Thirdly, this paper explicitly states that the essence of the middle-income trap is a vicious circle. Middle-income countries fall into it for either inefficient industrialization or slipping from the virtuous circle into it because of the endogenous "running out of steam" or the imported external shocks. Fourthly, this paper also puts forward the "debt-crisis-recovery-debt" vicious circle to specify the middle-income trap associated with excessive external debt. For one thing, these 
may serve as a supplement to existing literature. For another, they may also provide certain alerts and insight to help lessen the permanent loss for the middle-income economies when they develop recovery strategies in the current post-epidemic era.

The rest parts are organized as follows. Part two clarifies three significant definitions and discusses that helpful evidence from the existing literature. Through further literature and case study as well as data analysis, Part three, four and five explain why the debt crisis has a more serious impact on middleincome countries than other groups. To put all the evidence and reasoning together, in part six, the author constructs a mechanism focusing on a vicious circle where excessive sovereign debt initially serves as the trigger, then continues to work as an accelerator and impels the recession process. Part VII includes both conclusions and suggestions.

\section{DEFINITION CLARIFICATIONS AND LITERATURE REVIEWS}

\subsection{Middle-Income Trap}

Different researchers proposed divergent classification criteria of income groups $[6,9,10]$, while most literatures adopted the World Bank criteria. According to the World Bank Atlas method, one definition of the middle-income trap is that after an economy's GNI per capita reaches the middle level of the world, the economy stagnates for a long time. "Table 1" shows the threshold of each income group in different years.

Table 1. Part of the Historical Classification Criteria (GNI per capita in current U.S. Dollars) [11]

\begin{tabular}{lccccc}
\hline \multicolumn{1}{c}{ Group } & 1987 & 1997 & 2006 & 2018 & 2019 \\
\hline Low income & $<=480$ & $<=785$ & $<=995$ & $<=1,025$ & $<=1,035$ \\
Lower-middle income & $481-1,940$ & $786-3,125$ & $996-3,895$ & $1,026-3,995$ & $1,036-4,045$ \\
Upper-middle income & $1,941-6,000$ & $3,126-9,655$ & $3,896-12,055$ & $3,996-12,375$ & $4,046-2,535$ \\
High income & $>6,000$ & $>9,655$ & $>12,055$ & $>12,375$ & $>12,535$ \\
\hline
\end{tabular}

In "Figure 1", the author calculates the dynamic sizes of different groups including 218 economies according to the World Bank's criteria and data. Although 16 economies transferred from the middle-income group to the high-income group from 2006 to 2019 since the World Bank coined the "middle-income trap", 26 economies successfully crossed the poverty trap and joined the middleincome group with an even much smaller base number in 2006.

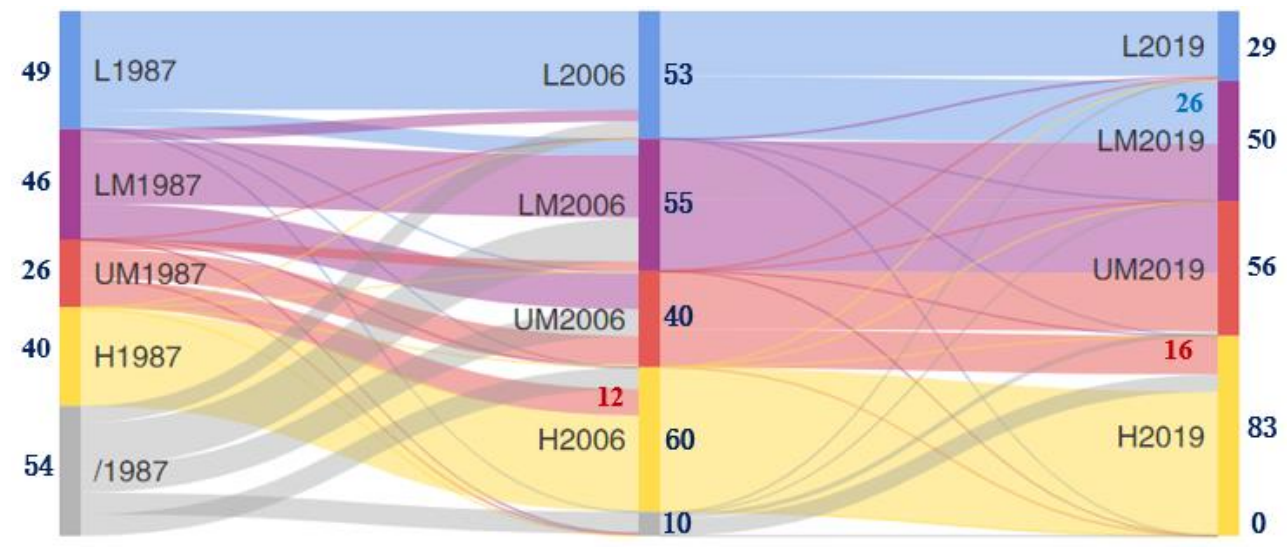

Figure 1 Dynamic sizes of different income groups.

Whether the trap does exist, and if so, what had caused most middle-income countries' falling into such trap have received considerable debates in literatures. One suggests that the economic growth runs out of steam, losing labor cost advantage over low-income countries while their technological advantage is not apparent compared with highincome countries. [12-18]. Besides, social 
development lagging behind economic development, generating social problems such as polarization between the rich and the poor, low rates of education, and bureaucratic corruption [19$21]$, is another well-known explanation.

In a nutshell, there is still no consensus on the existence of the middle-income trap and its causes. While in any case, it is true that most of the middleincome economies have failed to join the highincome group according to the World Bank's data, so this topic is still worth discussing.

\subsection{Debt Crisis}

"Middle-income traps" varies according to their divergent dominant triggers. This essay focuses on the rarely discussed type which is associated with the debt crisis. Debt crisis occurs when a state fails to service its outstanding sovereign debt on a considerable scale, thus defaults. "Figure 2" shows that the most recent default cycle encompasses the emerging market debt crises between the 1980s and 1990s, widely known as the Latin American debt crisis.

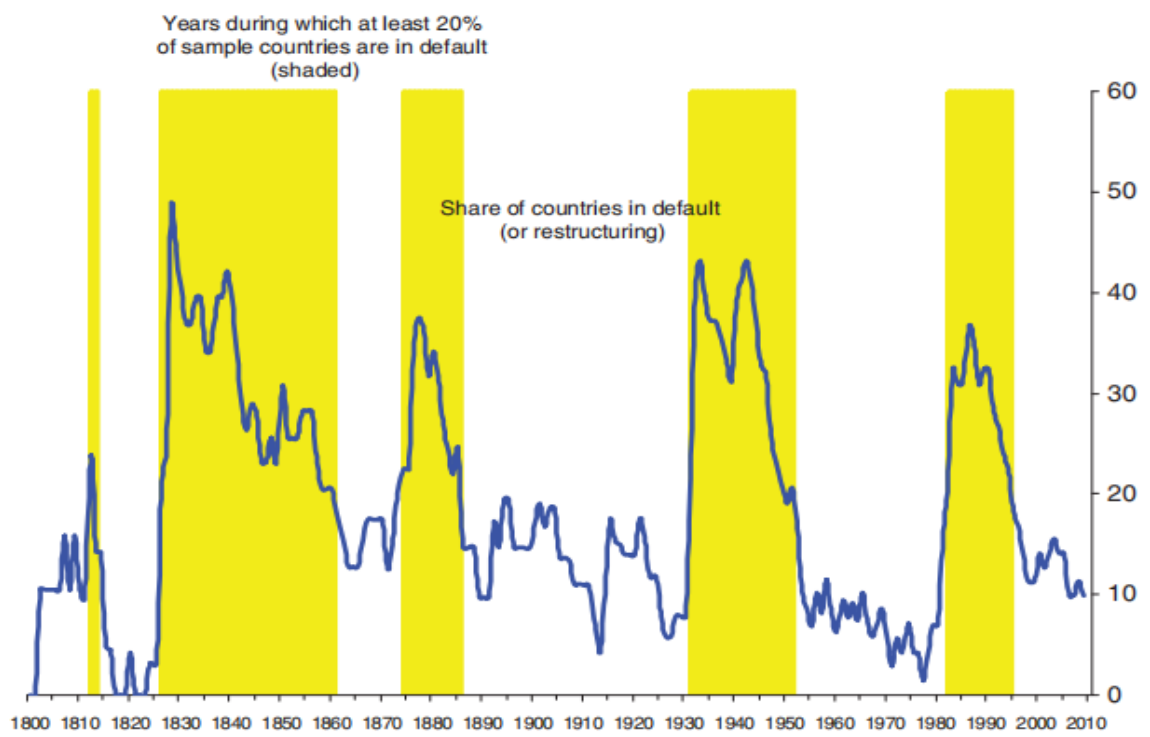

Figure 2 Global Sovereign External Default Cycles:1800-2009 (share of countries in default or restructuring)[22].

Latin American countries are typical representatives of the middle-income trap issue. Some scholars studying on the Latin American debt crisis have pointed out that there may be some causal relationship between the Latin American debt crisis and these countries' falling into the middle-income trap [7, 8]. However, few literatures have explicitly focus on the relationship between the two and discussed it in detail.

Additionally, some researchers found that various financial crises more significantly impacted developing countries than in developed countries [22]. This also provides strong support for this research

\subsection{Threshold Effect of External Debt}

The root of the debt crisis lies in excessive external debt. However, how to define and verify the real threshold of "excessive" is controversial due to its concealment. As long as the debt is used appropriately and reasonably to ensure substantial returns, increasing leverage can multiply the returns, thus promoting welfare [23-25]. However, once the debt exceeds a certain threshold, it may lead to a series of inefficient economic practices that undermine well-being. For example, high debt is likely to constrain the scope for counter-cyclical fiscal policies, which may result in higher volatility and further lower growth [26, 27]. The nonlinear effect of debt on growth is reminiscent of "debt intolerance" [28].

\section{FACT ONE: HIGHER ACTUAL RISK AND BURDEN OF SERVICE ON EXTERNAL DEBT IN MIDDLE-INCOME ECONOMIES}

Over the course of this research, the author simultaneously examines the World Bank data on the external debt ratio and the service on external debt since the 1970s in different groups then figures out a confusing paradox. "Figure 3" shows that low income group keeps a relatively higher debt ratio, 
so reasoning about their higher default risk and greater damage on output seems to hold water. In contrast, figure 4 reveals that the service rate on external debt is abnormally lower in these countries all the time. Even the external debt ratio peaked and surpassed the $100 \%$ waring line during 1995-1998, the service rate was controlled at around $10 \%$. At the same period, the service rate on external debt in middle income countries has long hovered near the $25 \%$ warning line. During 1980s and 1990s, this index even doubled in Latin American Countries (mostly middle income) than average and severe debt crisis occurred (see "Figure 3" and "Figure 5").

One significant fact is worth considering: Compared to Heavily Indebted Poor Countries (HIPC), middle-income debtor countries, with less debt relief and restructuring, take on greater actual burden in the face of both liquidity and solvency risks. According to the World Bank report, many heavily indebted poor countries benefit from debt relief initiatives and mechanisms. It is estimated that the debt stock of the 35 heavily indebted poor countries will fall by more than $80 \%$ at the postdecision point (corresponding to "Figure 3" in this article). This reduction has been accompanied by an increase in poverty-reducing spending in HIPCs of about 2 percent of GDP since the late 1990s [29]. Moreover, comparing the debt ratio levels before and after the surge and holdings reduction, the debt ratios of middle-income groups and Latin American groups have risen by nearly $10 \%$, while lowincome groups have almost returned to their original levels.

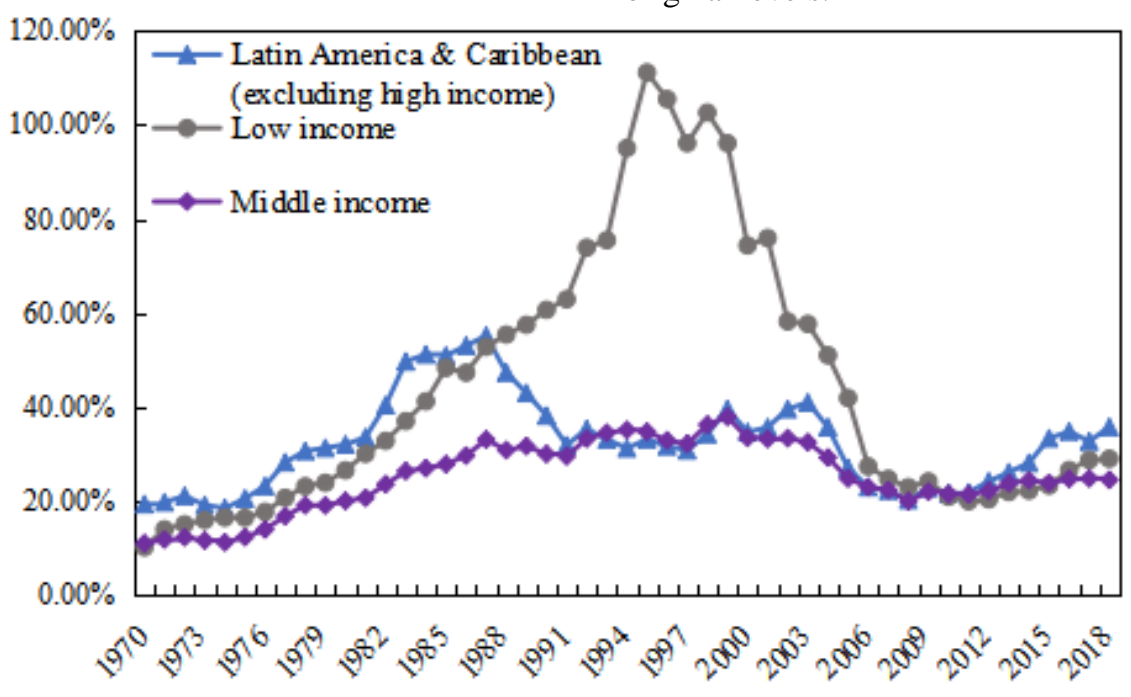

Figure 3 External debt to GDP Ratio.

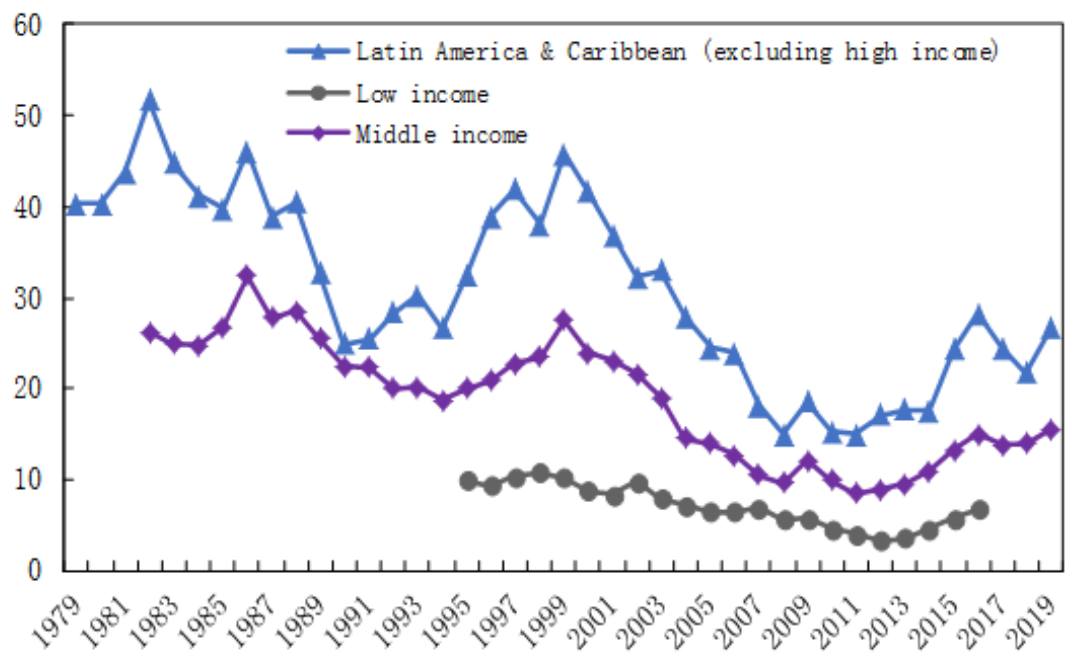

Figure 4 Debt Service on External Debt (\% of Exports of Goods, Services and Primary Income). 


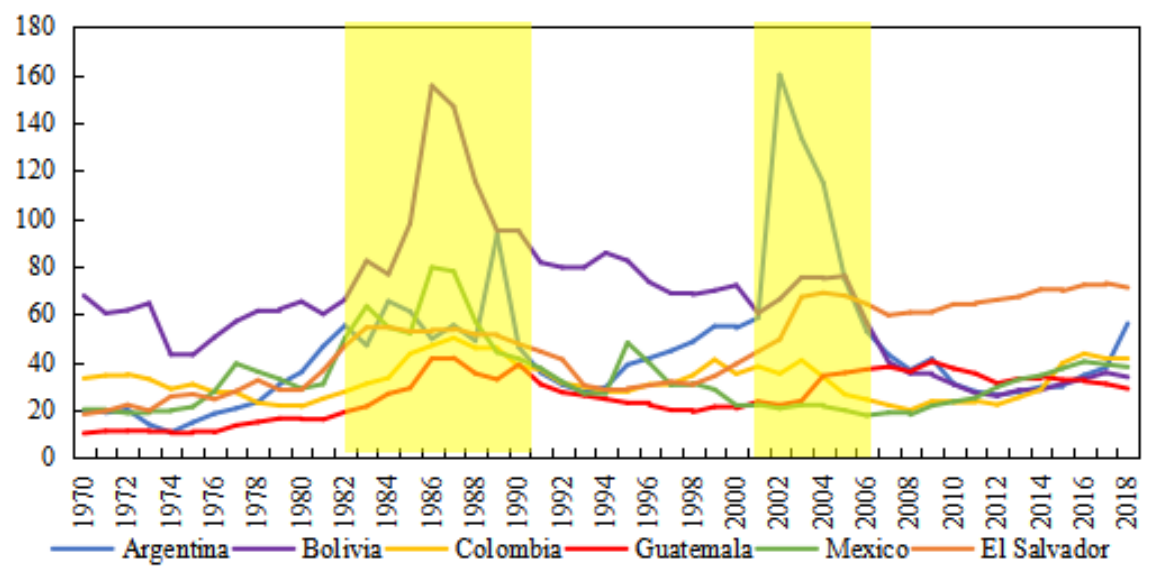

Figure 5 Surges of External Debt Ratio during Crises in Latin America.

\section{FACT TWO: THE DEBT RATIO THRESHOLD THAT TURNS TO HARM THE ECONOMY IS LOWER IN THE MIDDLE- INCOME ECONOMIES}

Debt is a double-edged sword. A certain amount of debt promotes economic growth while too much debt harms it. Existing empirical results show that debt threshold value is lower in the developing countries compared to that in the developed countries [22, 25], suggesting a weaker ability of middle-income countries to take on debt risk. According to Kevin Greenidge et al (2012), a 55$56 \%$ debt threshold, measured by debt to GDP ratio, statistically exists in the middle income countries [30]. However, as empirically proved, the OECD's debt ratio threshold is around 85\% [23]. Although few studies have clearly linked it to the middle-income trap, these empirical evidence all show that middle-income countries have a greater actual risk of falling into the trap. As showed in "Figure 5" above, Argentina, Bolivia, Mexico, and El Salvador exceeded the 55\% threshold and went through the debt crises in the 1980s and 2000s.

\section{FACT THREE: MORE SEVERE LOSSES IN MIDDLE-INCOME ECONOMIES THROUGH THE DEBT CRISIS}

\subsection{Theories: Two Types of Recovery from Shocks}

Theoretically, there are divergent statistical views of economic fluctuations based on different models. In Hamilton's model (1989) [31], the output is a random trend of Markov's transformation between positive and negative drift rates. Since a state transition occurs at the growth rate of the permanent output component, a negative state results in a sustained loss of output. The output returned to growth after the recession but remained on a parallel path below its original trend. Hence, in the long run, the countries that have been negatively affected fare worse than those that are not (see "Figure 6", left). On the contrary, in Friedman's plucking model (1993) [32], the output returns to its original trend during a rapidly growing recovery. Mean reversion shows that the shock has no long-term impact (see "Figure 6", right). Both models involve a "V-shaped" growth recovery, yet the Friedman model suggests that growth during recovery will be temporarily higher than during a normal expansion. 

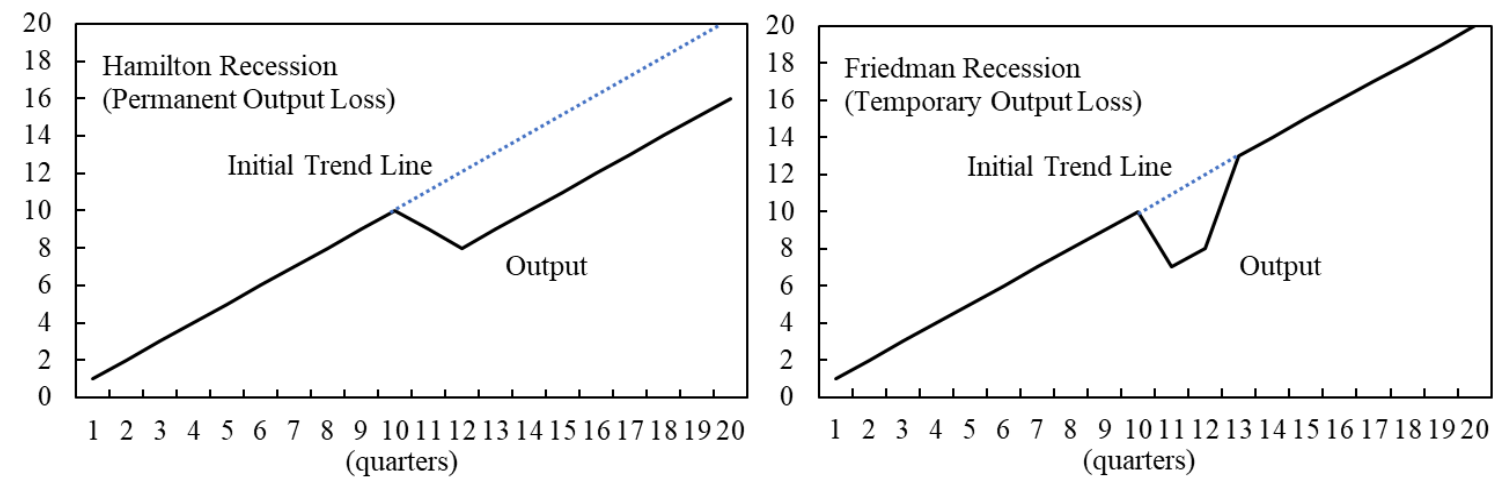

Figure 6 A Comparison between the Hamilton Recession and The Friedman Recession.

As a representative external shock, ( i ) does the debt crises derail growth, causing permanent output losses, or merely temporary ones? (ii). Is there a significant difference between the ability of different income groups to recover from the debt crisis? Therefore, the following parts further examine these two questions.

\subsection{Evidence: a Realistic View of the Recovery from the Debt Crisis}

Figure 7 provides evidence for the answer to question ( $\mathrm{i}$ ). As typical debt crisis sufferers in middle-income countries, Latin American countries, represented by eight such as Bolivia,
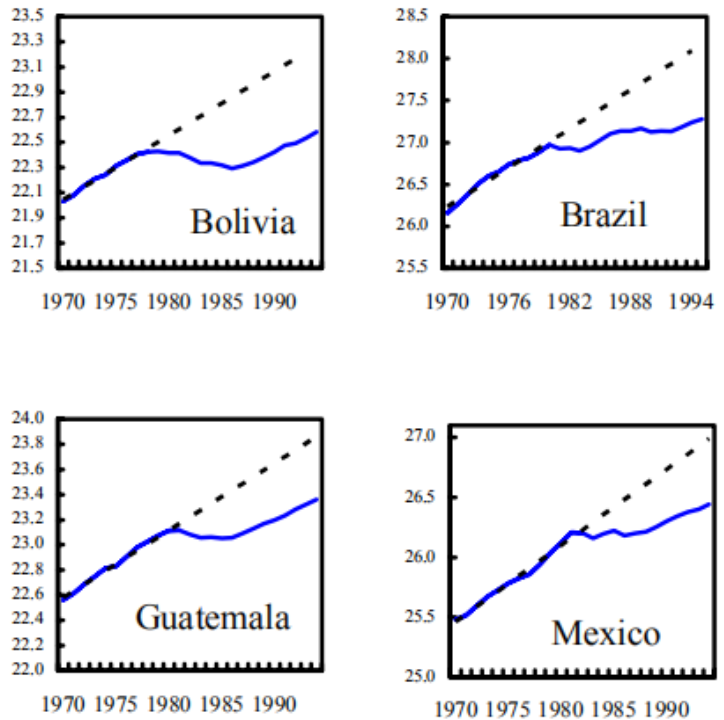

Brazil, and Chile, showed the characteristics of the Hamilton recession in the 1980s. Such shocks have generated a permanent loss of output.

In "Figure 8", recessions are divided into different income groups, where it shows that the lower-middle-income group holds the worst recovery effect (denoted by the orange dotted line). This was followed by the higher-middle income group (denoted by the blue dotted line), both below the average level (denoted by the blue line). Hence, it provides empirical evidence to answer the question ( ii ), namely, compared to the high income countries and even low income countries, middle-income countries are less capable of recovering from shocks such as the debt crisis.
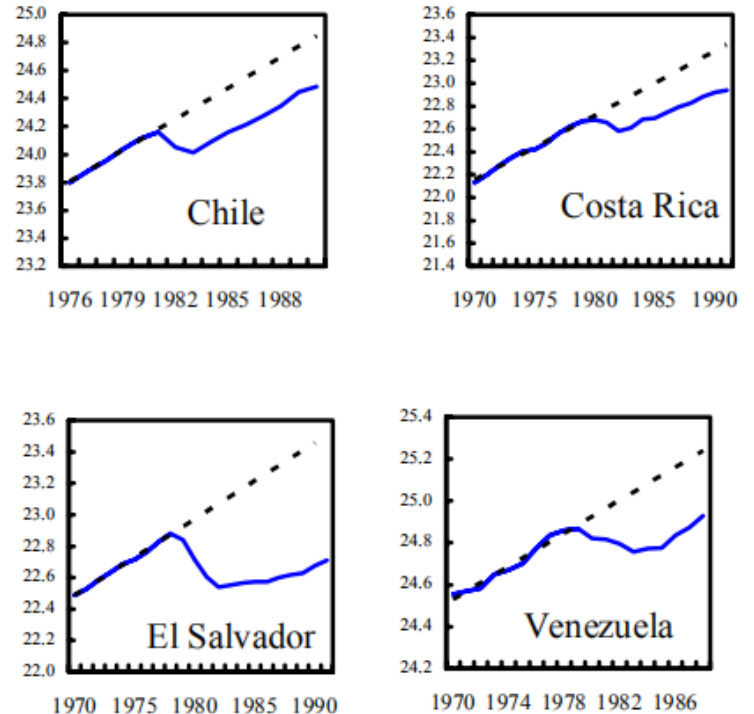

Figure 7 Debt Crisis of the 1980s[33]. 


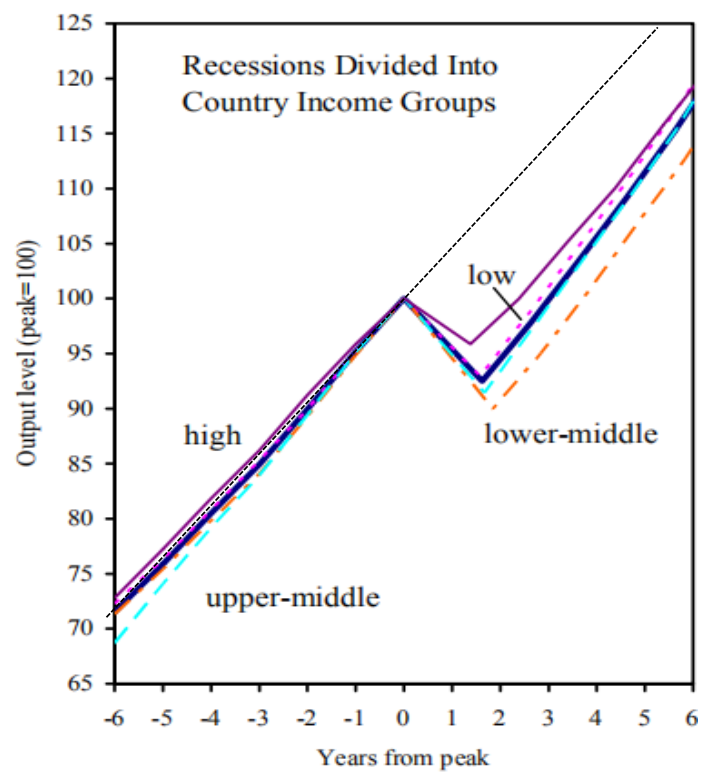

Figure 8 Recessions Divided into Country Income Group [33].

\subsection{Causes of the Permanent Loss after the Debt Crisis}

Roxburgh et al.(2010) found that a significant economic or financial crisis is usually followed by a lengthy deleveraging process lasting between five and seven years [34]. Given the heavier reliance on external debt to stimulate the economy in middleincome countries, deleveraging impacts will be almost a full range of depression. In the Latin American debt crisis, for example, the negative impact of the debt burden initially passed from the government sector to the enterprise sector due to the state-led industrialization strategy, then further conducted to the household sector through channels such as unemployment and low wages, which dampened both consumption and investment, then realized a spiral down of GDP. Worse still, compared with other types of financial crises such as bank crisis and currency crisis, debt crisis holds its particularity, which is induced by its direct impact on the balance sheet of the government sector. Given the excessive fiscal deficit resulted from the debt problem, the government's capacity to conduct a counter-cyclical regulation and smooth the fluctuation is weakened. For one thing, breaking the spiral downturn through an aggressive fiscal policy is thus unavailable. For another, easy monetary policy is also costly on account of the induced inflation risk, which will further generate severe currency devaluation and aggravate the external debt burden settled in foreign currencies such as U.S. dollars. That is to say, when domestic government macroscopical intervention policies fail, to a large extent, these countries have to count on external intervention to alleviate the problem, such as IMF's bailout and creditor's relief. While as a compensate, these debtor nations generally are required to agree on a series of treaties with the international organizations and creditor nations (e.g. Washington Consensus), along with a range of uncertain effects in the future. Hence, the remedial measures do not necessarily cover the loss of the debt crises.

\section{CIRCULAR MECHANISM OF "DEBT-CRISIS-RECOVERY- DEBT"}

In order to systematically explain the essence of the excessive-external-debt-induced middle-income trap and how these debtor countries fail to break free from it, a unified framework including both the 3 long neglected facts above and existing popular explanations were constructed in "Figure 9", while focusing on the formation of the "debt- crisisrecovery-debt" vicious circular mechanism. In this model, excess external debt serves as both the trigger and the accelerator.

For later-developing countries, in the early stage of development, achieving the primitive capital formation at home is deemed tough partly due to their losses in historical events such as colonization. In a game theory light, their action strategy space to conduct industrialization and develop the economy is severely limited. If a latedeveloping country lacks sufficient initial capital formation while maintaining a low national savings 
rate, sustainable development is very difficult. Because these countries not only have high social and civilian production costs, but also need continuous investment in infrastructure in the process of industrialization. Rationally, with the low interest rate stimulus of foreign loans, it is cheap thus attractive to borrow abroad. This is one of the dominant incentives.

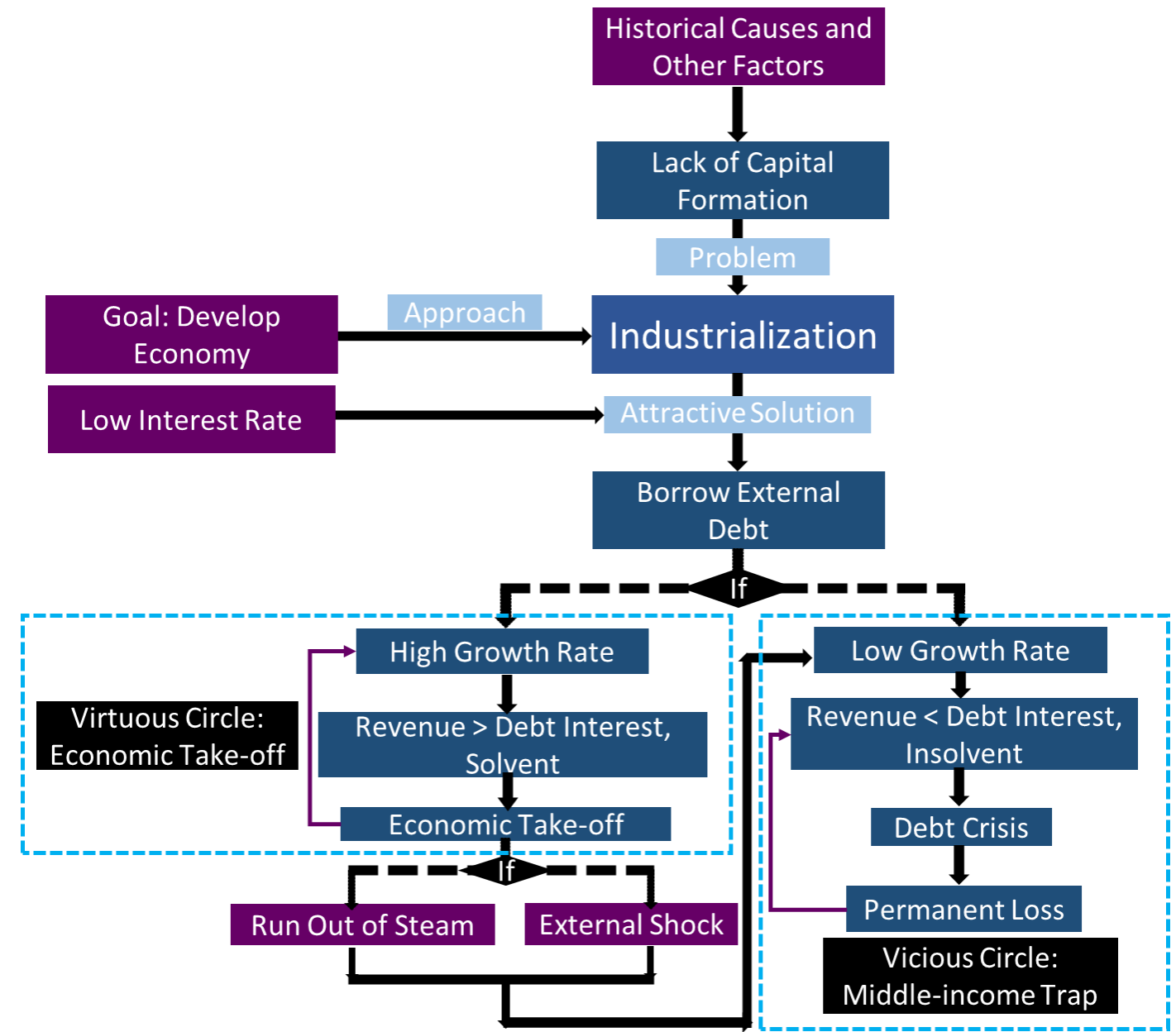

Figure 9 Circular Mechanism of "Debt- Crisis- Recovery-Debt".

Taking account of the efficiency in the use of capital and the implement effect of industrialization, there would be two possible cases coming into the discussion. In the first case, if the industrialization is poorly conducted, the economic growth will be driven by a low growth rate. Once the revenue of borrowing turns to be inferior to the cost of it, namely, the growth rate of output falls behind interest rate of foreign debt, excessive debt forms and debt service starts to erode the profit of output as well as the gross national income. To boost the economy while in the similar dilemma that being short of capital, these countries would be most likely to borrow more. However, if the efficiency of capital uses is not improved, continuing to borrow would make the insolvent problem worse. A low real debt ratio threshold should have released signal to constrain the government's borrowing decision while fails due to its covertness. Exorbitant debt ratio places a premium on the debt crisis, which statistically proved to cause permanent losses to the economy and the debt to GDP ratio deteriorates further during the recovery. One attractive possible solution to this is to kick the can down the road, constantly paying old debt with new ones, while with its credit lines and ratings lowered, this solution is unable to last too long. "Figure 10", calculated by author according to the WDI, shows the evidence on shifts from long-term debt to shortterm debt before the crises occurred. Unfortunately, this only works when the problem is merely about illiquidity instead of insolvency, thus such strategy is hardly sustainable without a constant high level of growth rate. 


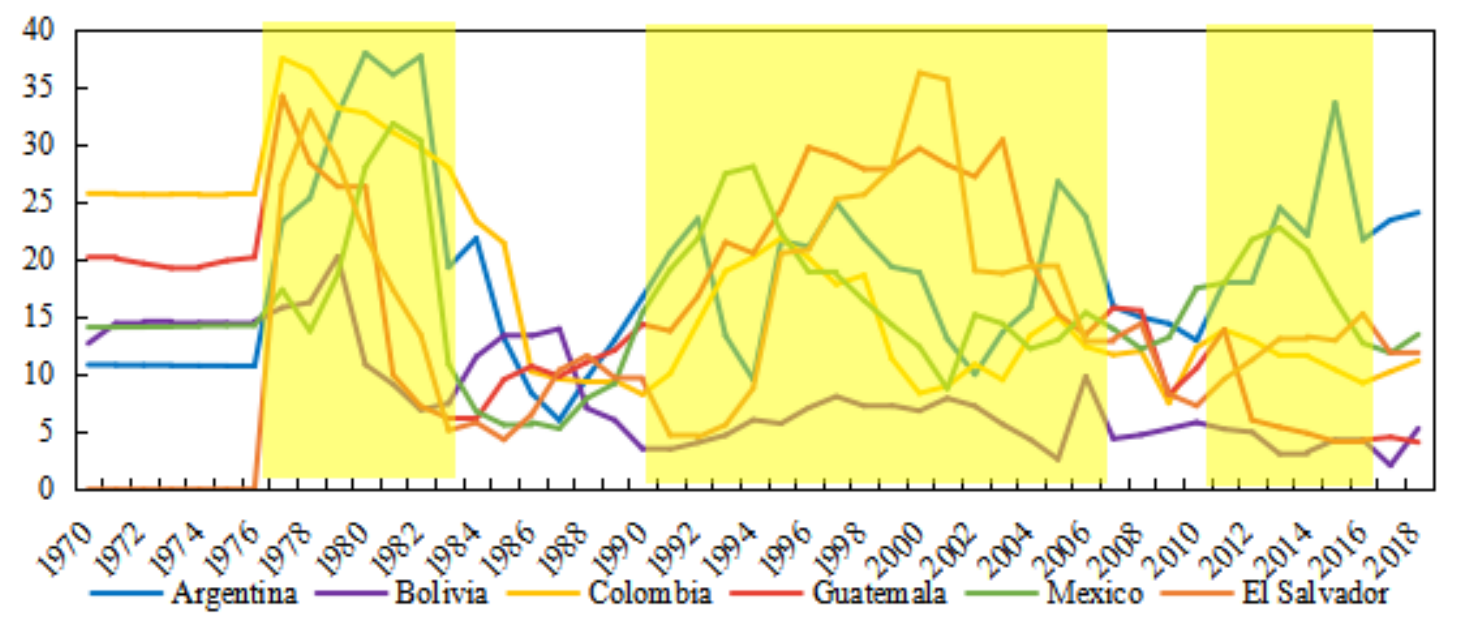

Figure $10 \quad$ Surges of Short-term Debt before and after the Crises in Latin America (\% of Total External Debt).

The analyses above have already revealed the core essence of both the middle income trap in the general sense and the middle-income trap induced by the excessive external debt in the specific sense. The traps are divergent vicious circle and those that associate with excessive external debt appears to be a "debt-crisis-recovery-debt" vicious circle. However, checking whether the mechanism also holds water in the case of high growth is necessary for the sake of integrity and rigor.

In the second case, if the industrialization is well implemented, with considerable capital formation from borrowing and efficient use of the capital, the economic take-off and virtuous circle is expectable. This explains the rapid growth in some middle income countries in the early phases. However, there are two forces underlying and likely to break this virtuous circle and induce the economy to slip into the vicious circle mentioned in the first case. One is the erosion of the original momentum, such as the extinction of demographic dividend, diminishing marginal returns to production factors, the widening income gap and government corruption. These are not the focus of this paper for they have been detailed debated and explicated in existing literature. The other is the imported external shocks. Latin American debt crisis in the 1980s, for example, had its roots in such external factors. After the oil shocks in the 1980s, the Federal Reserve, with the support of the Reagan administration and supply-siders, tightened monetary policy in response to severe stagflation, causing domestic interest rates to rise and pushing up the dollar, thus exacerbating the burden of dollar debt on the debtor countries. Finally, the debt crises broke out in these countries, resulting in permanent output losses. After that, the gains from economic growth tend to flow to debt payment rather than engaging in investment activities, along with a credit crunch. Eventually, the economy slipped and locked into the inextricable vicious circle of "debtcrisis-recovery-debt".

\section{CONCLUSION}

Establishing a direct link between the debt crisis frequency of occurrence and the middle-income trap is partly unavailable due to the limited data. Also, analysis of the debt ratio threshold has lacked sufficient rigorous empirical support. In this case, the next step of this research could be further empirically testing the threshold effect in different income groups. Be that as it may, the analyses above try to explain the middle-income trap focusing on a relatively novel perspective both theoretically and statistically. To a large extent, this paper is still enlightening in terms of the conclusions as below:

Firstly and unexpectedly, if the debt relief and restructuring initiative for HIPC and MDRI is not neglected, it is of the greater likelihood that middleincome economies take on a heavier burden on external debt service when compared to lowincome countries. At the same time, in comparison with high-income countries, the debt ratio threshold is relatively low yet secluded in middle-income countries. These two factors above combine and generate a higher risk of igniting the spark of debt crises.

Secondly, once the debt crisis does occur, permanent losses induced by such crises should be responsible for the stagnation and recession. 
Statistically, the extent of such permanent loss proved to be more severe in middle-income countries than that of the other two groups.

Thirdly and most importantly, to better explain the essence of such a trap and how those countries were caught too tightly to break free from it, introducing the "debt-crisis-recovery-debt" vicious circular mechanism makes sense. Confronted with limited strategic options, the rational laterdeveloping countries, stimulated by low-interest rates, tend to resort to external debt to accelerate economic output and yields, where the excessive debt serves as a trigger of the vicious circle. After the circle was activated, excessive debt transforms to be the accelerator of the recessionary course, eroding economic efficiency and slowing down the economic growth rate. Even Worse, once the sustained and sufficient rapid growth is no longer guaranteed, or a severe external shock was imported, the acceleration effect will be enhanced, as well as the significant risk of insolvency and default. The "debt- crisis-recovery-debt" vicious circle reveals the essence of the middle-income trap in the debtor countries and how these countries fail to save themselves from it.

Based on the conclusions above, this paper also proposes two suggestions as follows. For one thing, middle-income countries should be more cautious about borrowing and pay more attention to the real ratio of external debt threshold. For another, if debt crises break out in middle-income countries, it will be tough for them to break the vicious cycle and escape from the trap with domestic resources alone. In this case, international organizations and creditor countries should not only take care of HIPC but also pay attention to those heavily indebted middleincome countries. This is also to prevent these debtor countries from bringing more serious losses to the relevant global economy. In the context of rising sovereign debt risks in the current postepidemic era, these facts and suggestions may play an enlightening role.

\section{AUTHORS' CONTRIBUTIONS}

This paper is independently completed by Xiangru Zhou.

\section{ACKNOWLEDGMENTS}

First and foremost, I would like to show my deepest gratitude to Professor Paul ArmstrongTaylor from Johns Hopkins University, who provided me with valuable inspiration and guidance during the writing stage of this paper. Secondly, I would like to thank the faculties in Northwest University, without whom I would be incapable of mastering solid economic knowledge and skills to complete this research. Finally, I would like to thank my friends and parents for their support.

\section{REFERENCES}

[1] Homi Kharas and Harinder Kohli. 2011. What is the middle income trap, why do countries fall into it, and how can it be avoided? Global Journal of Emerging Market Economies 3. SAGE Publications Sage India: New Delhi, India: 281-289.

[2] Zhizhong Yao. 2014. What is the Real Middle-income Trap?International Economic Review: 75-88+6.

[3] Fang Cai. 2013. Avoiding the "Middle-income Trap" through Reform. Journal of Nanjing Agricultural University (Social Sciences Edition) 13: 1-8.

[4] Mr Shekhar Aiyar, Mr Romain A. Duval, Mr Damien Puy, Mr Yiqun Wu, and Ms Longmei Zhang. 2013. Growth slowdowns and the middle-income trap. 13-71. International Monetary Fund.

[5] Woo, Wing Thye. 2011. Understanding the middle-income trap in economic development: the case of Malaysia. World Economy Lecture delivered at the University of Nottingham, Globalization and Economic Policy: 17-34.

[6] Jesus Felipe, Arnelyn Abdon, and Utsav Kumar. 2012. Tracking the Middle-Income Trap: What is it, Who is in it, and Why? SSRN Electronic Journal. https://doi.org/10.2139/ssrn.2049330.

[7] Agénor, Pierre-Richard, Otaviano Canuto, and Michael Jelenic. 2012. Avoiding MiddleIncome Growth Traps. Economic Premise 98.

[8] Qingbo Gao.2015. "Debt Crises in Argentina: Origin, Trends and Prospects," International Economic Review 06(8):92-102.

[9] Inklaar, Robert, and D. S. Prasada Rao. 2017. Cross-Country Income Levels over Time: Did the Developing World Suddenly Become Much Richer? American Economic Journal: Macroeconomics 9: 265-290. https://doi.org/10.1257/mac.20150155. 
[10] Feenstra, Robert C., Robert Inklaar, and Marcel P. Timmer. 2015. The Next Generation of the Penn World Table. American Economic Review 105: 3150-3182. https://doi.org/10.1257/aer.20130954.

[11] World Bank Country and Lending Groups World Bank Data Help Desk. 2021. https://datahelpdesk.worldbank.org/knowledge base/articles/906519-world-bank-country-andlending-groups. Accessed January 29.

[12] Jankowska, Anna, Arne Nagengast, and José Perea. 2012. The Product Space and the Middle-Income Trap: Comparing Asian and Latin American Experiences. Organisation for Economic Co-operation and Development Centre Policy Insights 5. https://doi.org/10.1787/5k9909j2587g-en.

[13] Lee, Keun. 2013. Schumpeterian Analysis of Economic Catch-up: Knowledge, PathCreation, and the Middle-Income Trap. Cambridge University Press.

[14] Lin, Justin Yifu, and Volker Treichel. 2012. Learning from China's rise to escape the middle-income trap: a new structural economics approach to Latin America. The World Bank.

[15] Ohno, Kenichi. 2009. Avoiding the MiddleIncome Trap: Renovating Industrial Policy Formulation in Vietnam. Asean Economic Bulletin 26: 25-43. https://doi.org/10.1355/AE26-1C.

[16] Paus, Eva. 2012. Confronting the Middle Income Trap: Insights from Small Latecomers. Studies in Comparative International Development 47. https://doi.org/10.1007/s12116-012-9110-y.

[17] Paus, Eva, ed. 2013. Getting Development Right: Structural Transformation, Inclusion, and Sustainability in the Post-Crisis Era. New York: Palgrave Macmillan US. https://doi.org/10.1057/9781137333117.

[18] World Bank. 2010. World Bank East Asia and Pacific Economic Update 2010, Volume 2: Robust Recovery, Rising Risks. The World Bank. https://doi.org/10.1596/978-0-82138495-4.

[19] Refika Atalay. 2015. The Education and the Human Capital to Get Rid of the Middleincome Trap and to Provide the Economic
Development. Procedia - Social and Behavioral Sciences 174: 969-976. https://doi.org/10.1016/j.sbspro.2015.01.720.

[20] Zhang, Linxiu, Hongmei Yi, Renfu Luo, Changfang Liu, and Scott Rozelle. 2013. The human capital roots of the middle income trap: the case of China. Agricultural Economics 44: 151-162. https://doi.org/10.1111/agec.12059.

[21] Wen Cheng and Jianhua Zhang. 2018. "Income Level, Income Gap and Independent Innovation: The Formation and Escaping of the Middle-income Trap." Economic Research Journal 53(04):47-62.

[22] Carmen M. Reinhart and Kenneth S. Rogoff. 2011. From Financial Crash to Debt Crisis. American Economic Review 101: 1676-1706. https://doi.org/10.1257/aer.101.5.1676.

[23] Cecchetti, Stephen G., Madhusudan S. Mohanty, and Fabrizio Zampolli. 2011. The Real Effects of Debt. SSRN Scholarly Paper ID 1946170. Rochester, NY: Social Science Research Network.

[24] Craigwell, Roland, RCraigwell@imf.org, Kevin Greenidge, and KGreenidge@imf.org. 2012. Threshold Effects of Sovereign Debt: Evidence From the Caribbean. IMF Working Papers 12: i. https://doi.org/10.5089/9781475504507.001.

[25] Manmohan Kumar and Jaejoon Woo. 2010. Public Debt and Growth. SSRN Scholarly Paper ID 1653188. Rochester, NY: Social Science Research Network.

[26] Aghion, Philippe, and Enisse Kharroubi. 2007. Cyclical Macro Policy and Industry Growth: The Effect of Counter-Cyclical Fiscal Policy.

[27] Woo, Wing. 2009. Getting Malaysia Out of the Middle-Income Trap. SSRN Electronic Journal. https://doi.org/10.2139/ssrn.1534454.

[28] Reinhart, Carmen M., Kenneth S. Rogoff, and Miguel A. Savastano. 2003. Debt Intolerance. w9908. National Bureau of Economic Research. https://doi.org/10.3386/w9908.

[29] Primo Braga, Carlos A., and Doerte Doemeland. 2009. Debt Relief and Beyond. The World Bank. https://doi.org/10.1596/9780-8213-7874-8. 
[30] Crispolti, Valerio, and George Tsibouris. 2012. International Reserves in Low Income Countries: Have They Served as Buffers? SSRN Scholarly Paper ID 1997720. Rochester, NY: Social Science Research Network.

[31] Hamilton, J.D. 1989. A new approach to the economic analysis of nonstationary time series and the business cycle. Econometrica 57.

[32] Friedman, Milton. 1993. The "Plucking Model" of Business Fluctuations Revisited. Economic Inquiry 31: 171-177. https://doi.org/10.1111/j.14657295.1993.tb00874.x.

[33] Cerra, Valerie, and Sweta Chaman Saxena. 2008. Growth Dynamics: The Myth of Economic Recovery. American Economic Review 98: 439-457. https://doi.org/10.1257/aer.98.1.439.

[34] Roxburgh, Charles, Susan Lund, Tony Wimmer, Eric Amar, Charles Atkins, Ju-Hon Kwek, Richard Dobbs, and James Manyika. 2010. Debt and deleveraging: The global credit bubble and its economic consequences. McKinsey Global Institute: undefinedundefined. 